\title{
Effect of Plasma Welding Parameters on the Flexural Strength of Ti-6Al-4V Alloy
}

\author{
João Paulo LYRA E SILVA ${ }^{1}$ \\ Alfredo Júlio FERNANDES NETO ${ }^{1}$ \\ Luís Henrique Araújo RAPOSO ${ }^{2}$ \\ Veridiana Resende NOVAIS ${ }^{2}$ \\ Cleudmar Amaral de ARAUJO ${ }^{3}$ \\ Luisa de Andrade Lima CAVALCANTE ${ }^{1}$ \\ Paulo Cezar SIMAMOTO JÚNIOR ${ }^{4}$
}

\author{
${ }^{1}$ Department of Occlusion, Fixed Prosthodontics and Dental Materials, Dental School, \\ UFU - Universidade Federal de Uberlândia, Uberlândia, MG, Brazil \\ ${ }^{2}$ Department of Operative Dentistry and Dental Materials, Dental School, \\ UFU - Universidade Federal de Uberlândia, Uberlândia, MG, Brazil \\ ${ }^{3}$ Mechanical Engineering School, UFU - Universidade Federal de Uberlândia, Uberlândia, MG, Brazil \\ ${ }^{4}$ Health Technical School, ESTES, UFU - Universidade Federal de Uberlândia, Uberlândia, MG, Brazil
}

\begin{abstract}
The aim of this study was to assess the effect of different plasma arc welding parameters on the flexural strength of titanium alloy beams (Ti-6Al-4V). Forty Ti-6Al-4V and $10 \mathrm{NiCr}$ alloy beam specimens (40 mm long and $3.18 \mathrm{~mm}$ diameter) were prepared and divided into 5 groups $(\mathrm{n}=10)$. The titanium alloy beams for the control group were not sectioned or subjected to welding. Groups PL10, PL12, and PL14 contained titanium beams sectioned and welded at current 3 A for 10, 12 or 14 ms, respectively. Group NCB consisted of $\mathrm{NiCr}$ alloy beams welded using conventional torch brazing. After, the beams were subjected to a three-point bending test and the values obtained were analyzed to assess the flexural strength (MPa). Statistical analysis was carried out by one-way ANOVA and Tukey's HSD test at 0.05 confidence level. Significant difference was verified among the evaluated groups ( $<<0.001$ ), with higher flexural strength for the control group $(\mathrm{p}<0.05)$. No significant differences was observed among the plasma welded groups $(p>0.05)$. The NCB group showed the lowest flexural strength, although it was statistically similar to the PL 14 group ( $>0.05)$. The weld depth penetration was not significantly different among the plasma welded groups $(\mathrm{p}=0.05)$. Three representative specimens were randomly selected to be evaluated under scanning electron microcopy. The composition of the welded regions was analyzed by energy dispersive X-ray spectroscopy. This study provides an initial set of parameters supporting the use of plasma welding during fabrication of titanium alloy dental frameworks.
\end{abstract}

Key Words: energy dispersive spectroscopy, flexural strength, plasma arc welding, scanning electron microscopy, titanium alloy.

\section{INTRODUCTION}

The use of implants for prosthetic rehabilitation of edentulous patients is highly successful (1). However, a large part of the population remains without access to this treatment due to the inherent high costs. A considerable number of researchers attempted to optimize and simplify the original ad modum Brånemark implant rehabilitation with new techniques, alternative alloys and new welding methods, in an effort to expand the availability of dental implants (2-4). Several studies have examined alternative prefabricated frameworks employing titanium and Ti-Al-V (Titanium-aluminumvanadium) bars welded to titanium abutments to simplify manufacturing, decreasing laboratory effort, and reducing costs and treatment time, while still maintaining good fit and biocompatibility (2-4).

Titanium and its alloys are used for manufacturing dental prostheses because of their favorable biocompatibility, strength and modulus of elasticity.

Correspondence: Prof. João Paulo Lyra e Silva, Área de Oclusão, Prótese Fixa e Materiais Odontológicos, Faculdade de Odontologia, Universidade Federal de Uberlândia, Avenida Pará, 1720, Bloco 2B Sala 2B01, Campus Umuarama, 38401-136 Uberlândia, MG, Brasil. Tel: +55-34-3218-2222. Fax: +55-34-3218-2279. e-mail: joaodf22@hotmail.com 
However, the melting temperatures of these metals are near $1,700^{\circ} \mathrm{C}$, requiring special procedures and equipment for casting, heat treatment and coating to prevent contamination (5). Although at room temperature titanium is covered by an oxide layer $\left(\mathrm{TiO}_{2}\right)$ that provides corrosion resistance and biocompatibility, this metal is highly reactive at high temperatures and has a great affinity for hydrogen, nitrogen and oxygen. A reaction with these gases can decrease the properties of the material, so inert gas shielding is required during hightemperature processing $(6,7)$.

Manufacturing of dental prostheses usually requires permanent joining of metal components. Torch brazing welding is not effective in joining titanium or its alloys (8), and other welding techniques such as laser, TIG (tungsten inert gas) (9-11), and plasma methods (12) must be used. Plasma arc welding heats the material using a high-temperature ionized gas, and may be used to weld metals with excellent control and relatively low equipment cost (13). It produces joints superior to those obtained using torch brazing with alloys such as cobalt-chromium $(\mathrm{CoCr})$ or nickel-chromium $(\mathrm{NiCr})$ and also generates less distortion of the welded parts (9).

Few studies have described technical standards for evaluating prosthetic frameworks produced using plasma welding. Thus, the aim of this study was to assess the effect of different plasma arc welding parameters on the flexural strength of titanium alloy beams (Ti-6Al$4 \mathrm{~V})$ The hypothesis was that increased plasma welding periods would improve the flexural strength of Ti-6Al$4 \mathrm{~V}$ alloy beams.

\section{MATERIAL AND METHODS}

Forty $\mathrm{Ti}-6 \mathrm{Al}-4 \mathrm{~V}$ and $10 \mathrm{NiCr}$ alloy beam specimens were prepared $(40 \mathrm{~mm}$ long and $3.18 \mathrm{~mm}$ diameter) and divided into 5 groups $(\mathrm{n}=10)$. The titanium beams for the control group were not sectioned or subjected to welding. Groups PL10, PL12 and PL14 contained titanium beams sectioned and welded at a 3 A current for periods of 10,12 or $14 \mathrm{~ms}$, respectively. Group NCB consisted of NiCr alloy beams welded using conventional torch brazing. NiCr torch-brazed alloy beams and non-welded titanium bars served as negative and positive controls.

The titanium specimens were prepared from grade 5 circular Ti-6Al-4V alloy bars $3.18 \mathrm{~mm}$ in diameter ( $1 / 8$ in), as provided by the manufacturer (Realum, São Paulo, SP, Brazil). The bars of the control group were cut into 40-mm-long beams using a silicon carbide disk (Dentorium Products Co. Inc., Farmingdale, NY, USA) mounted in an electric motor (Kedel, Porto Alegre, RS, Brazil). The parts were cooled during cutting to minimize any possible distortion. Beams for groups PL10, PL12, and PL14 were cut into $20 \mathrm{~mm}$ pieces to provide a welding joint. The specimens for the NCB group were made using a silicone mold obtained from the prefabricated titanium bars and filled with autopolymerizing acrylic resin (Duralay; Reliance Dental Mfg Co., Worth, IL, USA) to obtain 20-mm-long and $3.18 \mathrm{~mm}$ diameter patterns, which were invested and next cast with $\mathrm{NiCr}$ alloy (Fit Cast-SB; Talladium do Brasil, Curitiba, PR, Brazil) using the lost wax technique $(15,16)$. The prepared bars were ultrasonically cleaned in distilled water for $5 \min (10)$.

For plasma welding procedures, the titanium bars were held in a fixture to ensure uniformity of the welding position. The titanium specimens were welded using a plasma arc welder (Micromelt; EDG, São Carlos, SP, Brazil). The parts were connected to the positive terminal of the device using a clamp. The plasma gas was grade 4.5 argon ( $99.95 \%$ purity) and the argon atmosphere was attained prior to welding. After verifying if the specimen was correctly positioned, the plasma arc welding pulse was initiated by pressing a foot pedal. The argon flow continued for $2 \mathrm{~s}$ after welding to allow cooling in an inert atmosphere.

For the NCB group, the NiCr bars were also placed in a metal matrix, to ensure correct positioning and uniformity of the welding position. The bars were then fixed and involved with autopolymerizing acrylic resin (Duralay; Reliance Dental Mfg. Co.). Then they were invested and heated at $750^{\circ} \mathrm{C}$ in a furnace to remove the acrylic resin index. Torch-braze welding procedures were carried out using a $1.0 \mathrm{~mm}$ diameter torch (Draeger; Labor Dental, São Paulo, SP, Brazil) with butane-propane/oxygen gas mixture and a $\mathrm{NiCr}$ based welding stick (Vera Solder; Aalba Dent Inc., Fairfield, CA, USA), which was used to join the $\mathrm{NiCr}$ alloy specimens.

After the welding procedures were carried out, the welded regions of all specimens were checked radiographically with occlusal films (IO-41; Kodak Insight, Kodak, NY, USA) to detect any defect represented by radiolucent points in the joint using a x-ray unity (Spectro 70X; Dabi Atlante, RibeirãoPreto, SP, Brazil).

The beams were tested for flexural strength in a 
three-point bending design in a device equipped with two rods of $3 \mathrm{~mm}$ in diameter and span-length of $20 \mathrm{~mm}$ (15). A compressive force was applied by a 3-mm-diameter tip positioned at the center of the specimen at a $0.5 \mathrm{~mm} / \mathrm{min}$ crosshead speed (11). The applied load was measured by a $500 \mathrm{~N}$ load cell attached to a mechanical testing machine (DL 2000; EMIC, São José dos Pinhais, PR, Brazil), adjusted to 4,500 N maximum load and collapse at $20 \%$. The test was considered complete when fracture or permanent plastic deformation of the beam occurred, until a maximum $5 \mathrm{~mm}$ displacement.

The flexural strength (MPa) was calculated using the following equation:

$$
f_{S}=\frac{8 . F \cdot L}{\pi D^{3}}
$$

where fs is the flexural strength in MPa, F is the determinant of fracture strength or elastic limit in N, L is the span-length, and $\mathrm{D}$ is the diameter of the beam in $\mathrm{mm}$.

The data were initially subjected to Shapiro Wilk and Kolmogorov-Smirnov tests for checking homoscedasticity. When homoscedasticity was confirmed, one-way ANOVA and Tukey's HSD test for multiple comparisons of means were used $(\alpha=0.05)$. Data were analyzed using SPSS 15.0 statistical software package (SPSS Inc., Chicago, IL, USA).

Afterwards, the plasma welded specimens were examined using stereomicroscopy at $\times 2.5$ magnification (Leica MS5; Leica Microscopy Ltd., Switzerland) to determine the degree of weld penetration in the fractured region. Images were captured and analyzed using a digital camera (Moticam 2000; Motic Instruments Inc., Richmond, Canada) and a computer software (MoticImages Plus 2.0 ML; Motic Instruments Inc.) to obtain measurements of the welding depth penetration.

Table 1. Flexural strength means (MPa) and standard deviations (SD) for the tested groups.

\begin{tabular}{lc}
\hline Group & Mean (S.D) \\
\hline Control & $2,781.88(38.86)^{\mathrm{a}}$ \\
PL10 & $1,552.02(180.31)^{\mathrm{b}}$ \\
PL12 & $1,470.35(105.56)^{\mathrm{b}}$ \\
PL14 & $1,354.34(315.19)^{\mathrm{bc}}$ \\
NCB & $1,145.35(206.55)^{\mathrm{c}}$ \\
\hline
\end{tabular}

Different letters indicate significant difference among the groups in rows $(\mathrm{p}<0.05)$.
The non-welded area was subtracted from the total cross-sectional area of the specimens and the results were analyzed again using the previously mentioned statistical tests $(\alpha=0.05)$.

Sequentially, three representative specimens fractured at the welded region for the different welding times (P10, P12 or P14) were randomly chosen to be evaluated under scanning electron microscopy (SEM). The specimens were mounted on aluminum stubs and the fractured surfaces were examined by SEM to check the welding penetration area and the characteristic of the failures (JSM 5600LV; JEOL, Tokyo, Japan). The composition of the welded regions was verified by energy dispersive X-ray spectroscopy (EDS).

\section{RESULTS}

The mean flexural strength values and standard deviations for the tested groups are presented in Table 1. One-way ANOVA indicated significant difference among the groups $(p<0.001)$, with a higher flexural strength for the control group. No significant differences were observed among the plasma welded groups $(p>0.05)$. The NCB group showed the lowest flexural strength values, although it was statistically similar to PL14 (Table 1). The welding depth penetration was not significantly different among the plasma welded groups $(\mathrm{p}=0.05)$ (Fig. 1).

SEM analysis of the fractured surface revealed effective welding only on the periphery of the specimens, with bubbles forming failures along the welded area (Fig. 2A) and presence of dimples (cavities characterizing

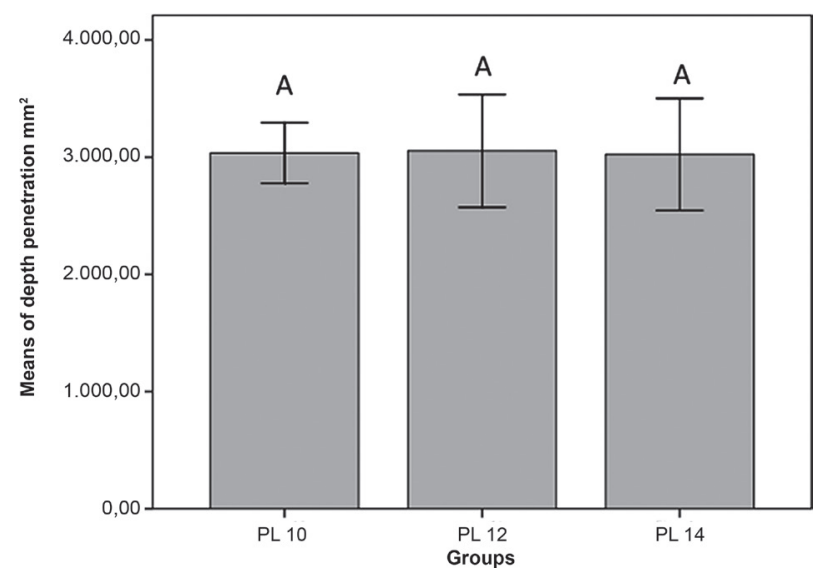

Figure 1. Depth penetration of plasma welded groups. Same letters indicate no significant difference among the groups $(\mathrm{p}<0.05)$. 
the ductile fracture surface) (Fig 2B). Cross-section reduction and heat affected zone at the welded region can be seen in Figure 2C. EDS analysis showed the presence of carbon, which is inherent to the technique and confirmed the presence of the alloy components $(\mathrm{Ti}, \mathrm{Al}, \mathrm{V})$ at the welded regions.

\section{DISCUSSION}

The hypothesis proposed by this study was fully rejected. There was no significant difference among groups welded using different plasma arc parameters. The flexural strengths of the plasma welded groups were lower than that of the control group, but superior to that of the torch-brazed group (Table 1).

Given the characteristics of titanium $(6,7)$ and its general application in restorative dentistry, there is a great need to improve welding techniques for manufacturing of prosthetic frameworks. Plasma welding equipment uses electric arc as the heat source. Although this is common in most modern fusion welding operations, plasma welding presents benefits, such as energy concentration in the base material to reduce the heat-affected zone, ease of control, relatively low equipment cost and an acceptable level of health risk for operators (13).

The plasma welding process was introduced for industry applications in the mid 1960's, being used in automobile and aircraft manufacturing, aerospace industry, among others. The first applications in dentistry were described for the repair of dental prostheses (16). Plasma arch was compared with laser for welding grade 2 titanium specimens and it was concluded that both procedures were suitable for welding this metal (12). After this, scientific assessments of the plasma welding technique are scarce in dental literature (17). This scenario is now being changed due to the development of a new plasma welding equipment, which uses a pulsed arc instead of a continuous arc as the one used in the
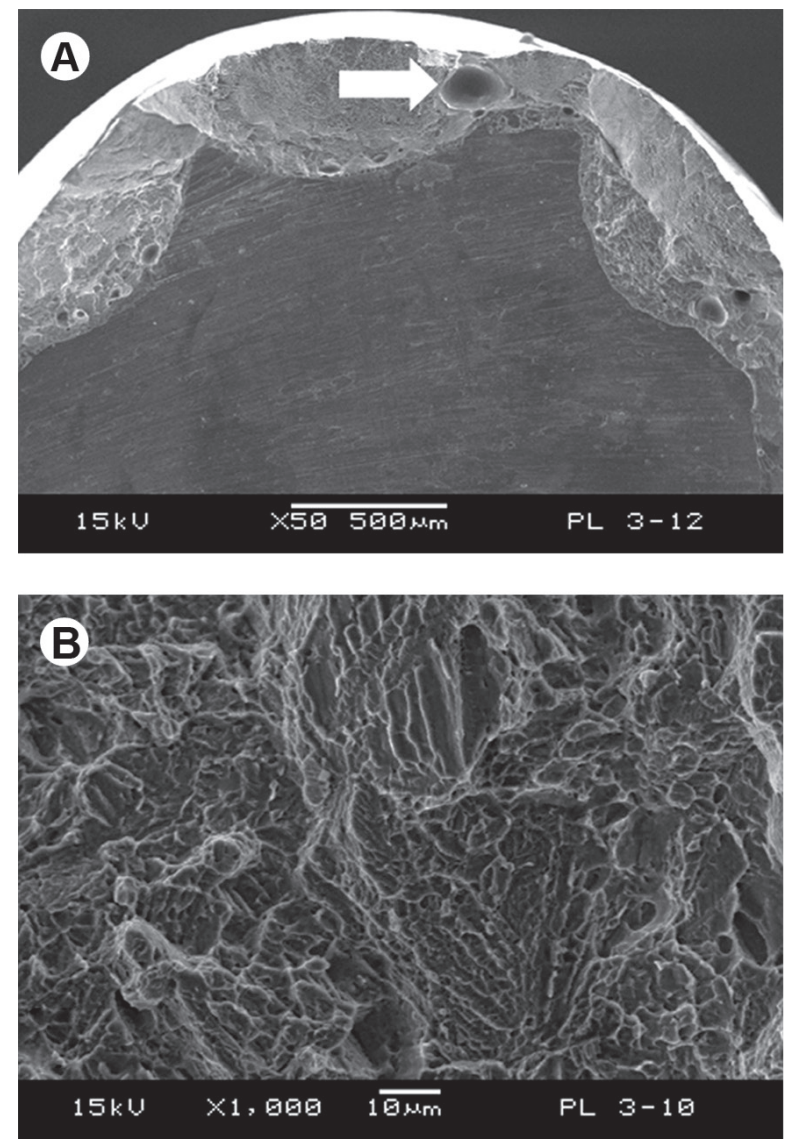

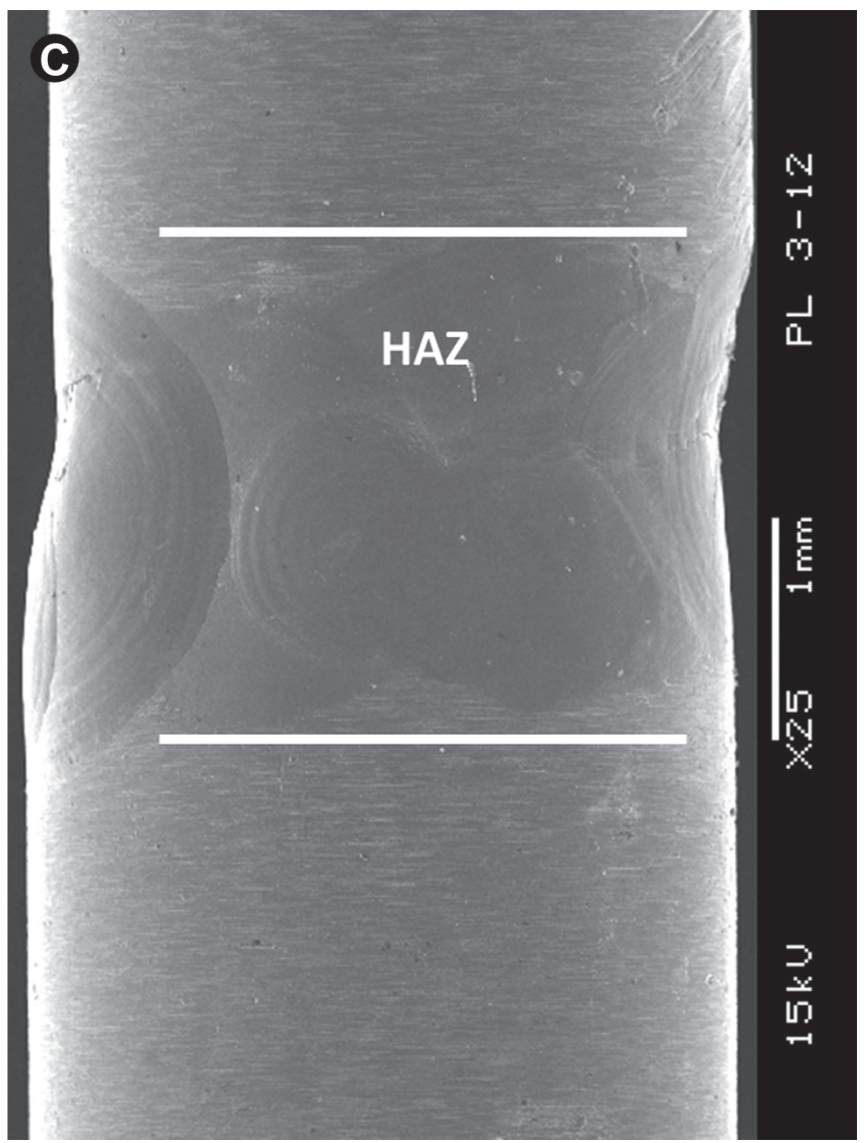

Figure 2. SEM micrographs of the welded surface. A: Fractured surface $(\times 50$ magnification $)$ shows bubbles forming failures along the welded area. B: Fractured surface $(\times 1000$ magnification $)$ shows the welded site with presence of dimples. C: Cross-section reduction at the welded region and heat affected zone (HAZ). 
previous welding equipment for industry and dental applications.

$\mathrm{NiCr}$ alloys are frequently used for manufacturing prosthetic frameworks to metal-ceramic restorations because of its ability to withstand several adverse conditions in the oral environment, such as the mechanical stresses (18). Apart from these characteristics, NiCrbased alloys are more accessible than the gold-based ones and this made these alloys very popular in the Brazilian prosthetic laboratories. This was the main purpose for using this alloy in the present investigation.

This study aimed to evaluate the effect of different plasma arc welding parameters, following a similar study that examined the parameters of time and voltage used in laser welding for dental restorations constructed of grade 1 commercially pure titanium (12). Data obtained from the three-point bending test provided important information required for the evaluation, but did not take into account the aging phenomena by thermo-mechanical fatigue (19). Although the present results cannot be applied directly to the clinical practice, they offer a broad background for calibration and training of operators and resources for standardizing the welding processes.

The lower flexural strength values found for the plasma-welded specimens when compared with the control specimens may be due to changes in the microstructure of the metal occurring during melting and solidification (Table 1) (20). Additionally, the lower flexural strength values can also be related to the incomplete welding of the titanium section, since only the periphery of the specimens was reached by the plasma arc, irrespective of the used welding parameters (Fig. 1). Thus, it is important to remove a minimum amount of material from the welded region during finishing and polishing procedures, since a reduction in the crosssectional area will reduce the strength of the framework (10). Prefabricated bars were employed in the present study aiming to restrict failures and distortions at the welded region.

The SEM analysis of the fractured specimens also revealed presence of bubbles entrapped at the welded regions for the plasma welded groups, which can be assumed as an important factor in reducing the flexural strength of these specimens (Fig. 2A). During welding, titanium reaches temperatures at which the metal has a high affinity for free elements such as oxygen, hydrogen and nitrogen, and incorporating these impurities could result in reduced strength (3). However, this was not verified in the present investigation, since the EDS analyses showed only the presence of the primary components of the used titanium alloy.

Failures occurred at the welded region in all specimens. The fractured surface of the plasma welded specimens showed the presence of dimples at the welded periphery, which is a typical characteristic of ductile metal failure with cup and cones (Fig. 2B). Analyzing the failure, the onset of fracture also appears to be determined by the presence of structural defects, which worked as stress concentration points (2A). The specimens typically presented imperfections or reductions in cross-section at the welded regions leading, in consequence, to lower ductility at these sites (Fig. 2C), according to Hart and Wilson (9). During image analysis, it was also noted that the welding contained voids, which might have decreased the resistance of the welded structure. This might have been because the parts were positioned without a gap and because no filler metal was used (17). This is a common practice in pulsed fusion welding and such limitation is also observed in laser welding (17), which is widely used for prosthetic manufacture.

Despite the limitations of plasma arc welding, the welded Ti-6Al-4V specimens exhibited higher flexural strength than the torch-brazed NiCr ones. This justifies investment in further research on plasma arc welding methods to improve the quality of prosthetic frameworks and to reduce the costs and manufacturing time.

Under clinical conditions, additional forces, such as masticatory or parafunctional forces, are also transferred to the prostheses. An additional limitation of this study is the absence of information regarding the durability of the welded joints. This may be obtained through mechanical and thermal cycling tests in order to investigate fatigue. These tests are insensitive to variations in hardness in the welded region and should therefore provide a better comparison between welded and non-welded samples.

Despite its inherent limitations, the present study provides an initial set of parameters to enable the use of plasma welding during fabrication of titanium alloy dental components, such as prosthetic frameworks. This is valuable information, since the welding industry currently markets their products while offering little application support, requiring users to empirically develop their own processes and setting parameters.

\section{RESUMO}

O objetivo deste estudo foi avaliar o efeito de diferentes parâmetros 
de solda a plasma verificando a resistência flexural de barras de liga de titânio (Ti-6Al-4V). Quarenta espécimes de Ti-6AL-4V e dez espécimes de liga de $\mathrm{NiCr}$ foram preparados (40 $\mathrm{mm}$ de altura e 3,18 mm de diâmetro) e divididos em 5 grupos ( $\mathrm{n}=10)$. As barras de liga titânio do grupo controle não foram seccionadas e nem submetidas a processo de soldagem. Os grupos PL10, PL12 e PL14, continham barras de titânio seccionadas e soldadas com uma corrente de 3 A por períodos de 10,12 e $14 \mathrm{~ms}$, respectivamente. $\mathrm{O}$ grupo NCB consistiu de barras de liga de $\mathrm{NiCr}$ soldadas pelo método de brasagem convencional. Em seguida as barras foram submetidas ao teste de flexão de três pontos e os valores obtidos foram transformados em resistência flexural (MPa). Análise estatística foi realizada usando ANOVA de fator único e o teste Tukey com o nível de significância de 0,05 . Diferença estatística foi verificada entre os grupos avaliados $(p<0,001)$, com os maiores valores pra o grupo controle. Não foram encontradas diferenças entre os grupos de solda plasma $(p>0,05)$. O grupo $\mathrm{NCB}$ apresentou os menores valores de resistência flexural embora tenha sido estatisticamente semelhante ao grupo PL14. Não houve diferença significante na profundidade de penetração entre os grupos de solda plasma $(p=0,05)$. Três espécimes representativos foram aleatoriamente selecionados para serem avaliados por meio de microscopia eletrônica de varredura. A composição das regiões soldadas foi verificada por meio de espectroscopia por energia dispersiva. Este estudo fornece informações iniciais de parâmetros para permitir a utilização de soldagem plasma durante a fabricação de estruturas em liga de titânio.

\section{REFERENCES}

1. Sadowsky SJ, Caputo AA. Stress transfer of four mandibular implant overdenture cantilever designs. J Prosthet Dent 2004;92:328-336.

2. Sierraalta M, Vivas JL, Razzoog ME, Wang RF. Precision of fit of titanium and cast implant frameworks using a new matching formula. Int J Dent 2012 [Epub ahead of print. DOI: 10.1155/2012/374315].

3. Barbosa GAS, Simamoto Júnior PC, Fernandes Neto AJ, Mattos MGC, Neves FD. Prosthetic laboratory influence on vertical misfit at the implant/UCLA abutment interface. Braz Dent J 2007;18:139-143.

4. Barbosa GAS, Bernardes SR, das Neves FD, Fernandes Neto AJ, de Mattos M da G, Ribeiro RF. Relation between implant/abutment vertical misfit and torque loss of abutment screws. Braz Dent J 2008;19:358-363.

5. Özen J, Ural AU, Dalkiz M, Beydemir B. Influence of dental alloys and all-ceramic material on cell viability and interleukin-1 beta release in a three-dimensional cell culture model. Turk J Med Sci 2005;35:203-208.

6. Poulon-Quintin A, Watanabe I, Watanabe E, Bertrand C. Microstructure and mechanical properties of surface treated cast titanium with Nd:YAG laser. Dent Mater 2012;28:945-951.

7. Craig RG. Cast and wrought base metal alloys. In: Restorative Dental Materials. 10th ed. Saint Louis, Mosby 1997:p428-432.

8. Titanium Information Group. Welding Titanium: A Designers and Users Handbook, Guide to best practice. Titanium Information Group 1999

9. Hart CN, Wilson PR. Evaluation of welded titanium joint used with cantilevered implant-supported prostheses. J Prosthetic Dent 2006;96:25-36.

10. Wang RR, Welsch GE. Joining titanium materials with tungsten inert gas welding, laser welding, and infrared brazing. J Prosthetic Dent 1995;74:521-530.

11. Rocha R, Pinheiro ALB, Villaverde AB. Flexural Strength of pure $\mathrm{Ti}$, Ni-Cr and Co-Cr Alloys submitted to Nd: YAG Laser or TIG welding. Braz Dent J 2006;17:20-23.

12. Roggensack M, Walter MH, Böning KW. Studies on laser- and plasma-welded titanium. Dent Mater 1993;9:104-107.

13. Cary HB. Modern welding technology. 4th ed. Ohio. Prentice Hall; 1998.

14. Santos-Filho PC, Castro CG, Silva GR, Campos RE, Soares CJ. Effects of post system and length on the strain and fracture resistance of root filled bovine teeth. Int Endod J 2008;41:493-501

15. Anusavice KJ, Okabe T, Galloway SE, Hoyt DJ, Morse PK. Flexure test evaluation of presoldered base metal alloys. J Prosthet Dent 1985;54:507-517.

16. Cottin, G. Plasma technique of arc welding in the repair of the dental prosthesis. Rev Fr Prothese Dent 1980:31-39.

17. Chai T, Chou CK. Mechanical properties of laser-welded cast titanium joints under different conditions. J Prosthetic Dent 1998;79:477-483.

18. Nuñez-Pantoja JM, Vaz LG, Nóbilo MA, Mesquita MF. Fatigue performance of joints executed in pure titanium structures with several diameters. Dent Mater J 2011 [Epub ahead of print. DOI: 10.4012/dmj.2011-112].

19. Gil FJ, Planell JA. In vitro thermomechanical ageing of Ni-Ti alloys. J Biomater Appl 1998;12:237-248.

20. Neo TK, Chai J, Gilbert JL, Wozniak WT, Engelman MJ. Mechanical properties of titanium connectors. Int J Prosthodont 1996;9:379-393.

Received February 14, 2012

Accepted November 30, 2012 